\title{
KULTURA HELLEŃSKA W ŚWIETLE PROGRAMU WYCHOWAWCZEGO AMFILOCHIUSZA Z IKONIUM*
}

Problem stosunku plerwotnego Kościoła do kultury helleńskiej był 1 jest nadal przedmiotem wielu analiz 1 dociekań. Autorzy starają slę możliwie wszechstronnie przedstawié sposób, w jaki myśl chrześcijańska asymilowała pierwiastki kultury helleńskiej. Czynia to zaś bądź przy pomocy ujęć syntetycznych, bądź też na przykładz1e poszczególnych ojców Kościoła. W niniejszym artykule przyjęto, jak wynika z tytułu, drug1 z wymienionych sposobów ujęcla tematu, zawezzony jeszcze dodatkowo do aspektu wychowania.

Ważność kwestil wychowania wierwotnym chrześcijaństwie staJe sle zrozumiała, jeśl1 weźmie slę pod uwage, że wiele form kultury grecko-rzymskiej było zupełnie nie do przyjęcia dla ówczesnych chrześcijan,a niektóre z nich mogły wywierać szczególnie zgubny wpływ na młodzlez. Kościóz zatem czuł sia zobowizzany wypracować wasny model nychowania, który byłby nastawiony na zawarte w nauce Chrystu8a wartości objawione, a jednocześnie alsceptować pozytywne wartośc1 hellenizmu. Podstawy do wypracowania takiego modelu dał juź św. Paweł, który nakazywał chrześcijańskim rodzicom tak postępować, aby wdrazać dzieci w wartości religijno-moralne oraz nie wzbudzać " nich niechęc1 do źycia na poziomie chrześcijańskim /EP 6, 4; Kol 3, 21/;

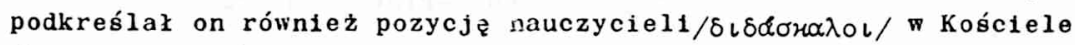
$/ 1$ Kor 12, 28/. Ogólnie można powiedzieć, że św. Paweì rozumle wychowante chrześcłjańskie jako wpajanie dzleciom zdrowej karności

* Podstawowym źródłem do opracowania niniejszego tematu był poemat dydaktyczny Amfilochiusza z Ikonium pt. "Jamby do Seleukosa" wydany krytycznie przez E. Oberga: Amphilochius Iconiensis, Iambi ad Seleucum, Berlin 1969; Jego przekład w niniejszym zeszycie

s. $711-723$ 
w zyciu moralnym, co jest miarą postępu w stosunku do tradycji wychowanta rzymskiego ${ }^{1}$. We wczesnej, sięgającej jeszcze czasów apostolskich, tradycji patrystycznej ciekawe sformułowanie dotyczace poruszanego tutaj zagadnienia moźna znaleźć u Klemensa Rzymskiego. Mów1 on mianowicie o wychowaniu młodzienców w bojaźni wobec Boga ${ }^{2}$. "Didache" natomiast akcentuje za ́́ Widać zatem, ze obok rodziny, której rolę w kształtowaniu świadomośc1 religijnej podkreślała tradycja żydowska", chrześcijaństro nskazuje takze na nauczyciel1, jako na ważnych pomocników w tym trudnym dziele. Dla lepszego zrozumienia pozycji nauczycieli wościele pierwotnym należy się jeszcze odwołać do "Pasterza" Hermasa. Widać juz $w$ nim wyraźnie hierarchiczny charakter władzy wościele, a m1mo to nauczyciele nadal zajmuja miejsce równe Apostołom, biskupom 1 diakonom ${ }^{5}$. Należy jednak zwrócić uwage na to, ze przedstawiony wyzej konturowy zarys progranu chrześcijańskiego wychowania siega swymi korzeniami do najgłęszych warstw hellenizmu. Role wychowania mocno akcentowano $w$ starozytnej Grecj1, a teoriami wychowawczymi zajmowali się najwybitniejsi myśliciele Hellady. Za pierwszego teoretyka pedagogiki uwazali Grecy Pitagorasa ${ }^{6}$. Pewien jednak okreslony system wychowawczy zbudował dopiero Platon. Podkreślar on, ze $" / .$. / podobnie jak w Innych dziedzinach źycia, tak zwłaszcza wychowaniu, nadzwyczaj doniosły jest początek, poniewaz przypada on na najwczé́niejszy 1 najbardziej wraźliwy okres rozwoju człowleka. W mlodym wieku jest sie najbardziej podatnym na wpłyny 1 wycí́nięte wówczas na duszy człowieka znamię/gr. "typos" - odbicie/, pozostaje $w$ niej na zawse $n^{7}$. Po Platonie oryginalna teorie peda-

1 H. I. Marrou, Historia wychowania w starozytności, tłum. S. Loś, Warszawa 1969, 435 .

2 Clemens Romanus, Epistula ad Corinthios 21, 6, SCh 167, 138. POK 1, 128.

3 Didache 13, 2115,2 , SCh 248, 1901194, POK 1, 37138.

4 H. I. Marrou, dz.cyt., 435.

5 Hermas, Pastor, Visio III 5, 1, SCh 53, 110, POK 1, 297.

6 A. Danysz, Uwagi o pedagogice Pseudo-Piutarcha, "Eos" 14/1908/ 188.

7 W. Jaeger, Paidela, t. 2, przeł. M. Plez1a, Warszawa 1964, 260. 
gogiczna strorzył Arystoteles opierając jz na psychologii 1 etyce ${ }^{8}$. Nedług Stagiryty człowiek nierozwinig̨ty/nieukształtowany/może siq rozwijac tylko pod wpływem człowleka rozwiniz̨tego/ukształtowanego/. Ten wpływ dorosłego na młodzienca nazywa się wychowaniem. Na określenie działania wychowawczego stworzył Arystoteles osobny termin -

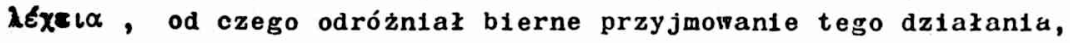

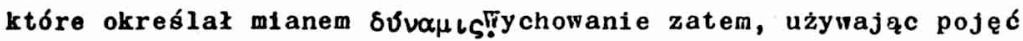
arystotelesowskich, jest entelechiz ludzką, działająca na ludzką dynamis. Kres działań wychowawczych następuje wtedy, gdy rozwój osobowości jestskończony, lub kiedy wychowanek na tyle jest samodzielny, ze we wasnym zakresie moze prowadzić pracę nad swym rozwojem $^{9}$. Na gruncie rzymskim autonomiczna teorie wychowania stworzy Kwintylian, czyniąc ja częścią teorii retorycznej ${ }^{10}$. We wstępie do "Inst1tutio oratoria" Kwintylian podkreśla, że mówcą może byé tylko vir bonus, a do tego potrzeba nie tylko zdolności oratorskich, lecz takze zalet umysłu oraz wiedzy, czyl1 wartości nabywanych w procesie wychowawczym ${ }^{11}$.

Jak widać juz chociażby z tego krótkiego zestawienia teoril wychowawczych, chrześcijaństwo budowało swój system wychowarczy na silnych wielowiekowych fundamentach. Można tutaj oczywiście wskazywad na to, ze nie wszystko w zastanych modelach było dla religil Chrystusowej do przyjęcia, niemniej jednak wazny jest sam rakt 1ch 1stnienia 1 Iunkcjonowania. Ich doświadczenia pozwoliły wypracowaé to, co dziś nazywa sie "wychowaniem chrześcijańskim".

Po tym zwięzłym omówieniu teorii wychowawczych, wypada pośrięcić nieco uwagi twórcy prezentowanego tutaj programu wychowawczego - Amfilochiuszowi z Ikonium. Urodziz sie w Kapadocji ok. $340 \mathrm{r}$. 1 był stryjecznym bratem Grzegorza $z$ Nazjanzu ${ }^{12}$. Studiował retoryke w Antiochil u Libaniosa, a następnie przez kilka lat by $ł$ adwokatem w Konstantynopolu ${ }^{13}$. W $373 \mathrm{r}$, pod wpływem św. Bazylego,zgodz1ł sie

8 A. Danysz, jak wyżej.

9 A. Danysz, Pedagogika Arystotelesa, "Eos" 10/1904/, 44.

10 A. Danysz, Teoria pedagogiczna Kwintyliana, "E S" 5/1898-1899/, 171.

11 Tamze, 172.

12 P. Gallay /La vie de S. Grégolre de Nazianse, Lyon-Paris 1943, 251/ podaje tablice zawierająca liste krewnych Grzegorza. Por. takze J. Stahr, Listy Grzegorza, POK 15, LIII. T. Sinko, Literatura grecka, Wrocław 1954, t. 3, cz. 2, 135. 
na objęc1e godnośc1 biskupa metropolity Ikonium ${ }^{14}$. Okres, w którym przyszło mu działać, to apogeum postępów arıanızmu na Wschodzie. Wystąpienia w obronie ortodoksj1 na Soborze Konstantynopolitańskim I w 381 r. przyniosły mu znaczny rozgłos. Cesarz Teodozjusz uznał go bowiem wraz z optimusem z Antiochil pizydyjskiej za oficjalnego przedstawiciela ortodoksji, z którym, jeśli się nie chciało być heretykiem trzeba było pozostawać we wspólnocie kościelnej ${ }^{15}$. Po synodzie wonstantynopolu $\$ 394$ r., w którym brał udział, nikną jego historyczne ślady, z czego rómnież wynikaja różnice odnośnie daty śmierci, spotykane woszczególnych opracowantach. Większość autorów opowiada się za latami $394-396^{16}$, Jako prawdopodobna data śmierci, choć niektórzy przesuwaja ja nawet na rok $403^{17}$. Sw. Bazyli, mistrz $i$ przyjaciel biskupa Ikonium, w jednym z listów adresowanych do niego, podkreślał jego wielka pilność w pracy, nawet nocaz przy kaganku ${ }^{18}$; cenił go także jako doradcę ${ }^{19}$. Był równiez pełen podziwu dla jego filologicznej ścisłośc1 w badaniu Pisma św. ${ }^{20}$, oraz wyrażał swoje uznanie dla jego naukowych zamiłowań ${ }^{21}$. Dla charakterystyki biskupa Ikonium nie bez znaczenia jest równiez opinia św. Hieronima, który nie wahał się go umieścić w jednym rzędzie ze św. Bazylim $i$ Grzegorzem z Nazjanzu 22 . Słowa pełne podziwu i uznania kierował pod jego adresem również Teodoret z Cyru sławiąc go zarówno jako biskupa ${ }^{23}$, jak 1 jako obrońcę wiary przeciw arianizmowi 24 .

Jeśli chodzi o dorobek literacki omawianego autora to trzeba podkreślić, ze zachowały się z niego zaledwie Pragmenty 25 . Ni-

14 Basilius, Epistula 138, 2, PG 32, 580 C-581 A; por. tez: Epistula 161,2 , PG $32,629 \mathrm{C}$.

15 T. Sinko, dz.cyt., 135.

16 Por. SWP 31; por. téz: B. Altaner, Patrologie, Freiburg 1980, 308 oraz T. Sinko, dz.cyt., 135.

17 F. Cayré, Précis de Patrologie, Paris 1927, t. 1, 419.

18 Epistula 232, PG 32,864 B.

19 Epistula 201, PG 32, $736 \mathrm{~B}$.

20 Epistula $188,15, P G 32,681 \mathrm{C}$.

21 Ep1stula 199, PG 32, 716 C.

22 Hieronimus, Epistula 70,4, PL $22,667$.

23 Theodoretus Cyrensis, Historia ecclesiastica IV 9, PG 82, 1144 B.

24 Tenże, leligiosa historia 1, PG 82, 1299 A-B.

25 Por. PG 39, 9-130. Pełny wykaz zachowanych dzieł Amfilochiusza podaje M. Geerard, CPG 2, 230-239, a $1 \mathrm{ch}$ wydanie por. C. Datema, 
niejsze opracowanie bazować bęuzie w całości na jego poemacie dydaktycznym noszącym tytuł "Jamby do Seleukosa". Dzieło to bardzo długo było przyplsywane Grzegorzowi z Nazjanzu. Jako podstawowy argument na to przytaczano zgodność myśli 1 wyrazeń, uzytych v tym utworze, z poematami Grzegorza "Ad alios"26. Obecnie poemat ten przypisuje sie powszechnie Amfilochiuszowi, powołujac się miedzy innymi na fakt, ze autorstwa Grzegorza nie potwierdza zaden z zachowanych kodeksów, ani też zaden z autorów starożytnych ${ }^{27}$. Jéli chodzi o czas powstania poematu, to przyjmuje sie dziś okres na krótko po śmierci św. Bazylego /379/ lub po Soborze Konstantynopolitańskim /381/, choć niektórzy badacze powołując się na wyniki krytyki wewn̨̨trznej "Jambów" skłonni są przesuwać tę datę nawet poza rok 387 . Jednakze E. Oberg, wydawca krytycznego tekstu poematu, uważa ten argument za wątpliwy ${ }^{28}$. Jeśli chodzi o strukturę dzıeła to składa sį̧ ono z 340 wierszy napisanych trymetrem jambicznym. Prócz stosunku do kultury helleńskiej Amfilochiusz dotknął w nim równiez kwesti1 trynitarnej. Przedstawił ortodoksyjną naukę - Trójcy św. /w. 193-199/, a następnie napiętnował dwie herezje trynitarne, szczególnie groźne dla ówczesnego Kościoła: sabelianizm i arianizm/w. 200-207/. Jako zaś wzór życia chrześcijańskiego wyeksponował Mojzesza /w. 219-239/. Starał się on takze uczulić czytelników na krązące wówczas apokrypy, podszywające się pod miano Pism natchnionych /w. 251-260/. Podaje wreszcie kanon Starego 1 Nowego Testamentu, co stanowi jednaz $z$ najwartościowszych części

Amphilohil Iconiensis opera, orationes, pluraque alia quae supersunt, nonnulla etials spuria, Turnhout $1978=$ CCG 3 .

26 Carmina II, II 8, PG 37, 1577-1600. Por. T. Sinko.dz.cyt., 136.

27 Por. E. Oberg, Amphilochius Iconiensis, Jambi ad Seleucum, Beriin 1969, 1 .

28 Tamże, 3. Zwolennicy powstanta poematu po roku 387 porołuja sie na to, iz w ostatnich jego wierszach /w. 335-337/ Amfilochiusz wychwala olimpiadę, osobe blisko zwi zzanaz z dworem cesarsk1m, która ok. $387 \mathrm{r}$. odnówiła powtórnego wyjścia za mzż, mimo wyraźnych nalegań ze strony cesarza Teodozjusza. Taka postawę chwalono bardzo w ówczesnym Kościele, co współczesnym krytykom dało podstaw do wniosku, ze pochwała biskupa Ikonium odnosi siq do tego właśnie wydarzenia $E$. Oberg podkreśla Jednak, ze kodeksy nie sa z soba zgodne coldo liczby wierszy, stad téz ostatnie z nich moga byé póníniejsza interpolacją. 
poematu /w. 263-319/. Jeśl1 chodzi o Stary Testament to autor przytacza w nim trzydzieści osiem ksiag, ponijając w stosunku do obecnego kanonu osiem następujących: Księga Tobiasza, Judyty, dwie Księgi Machabejskie, Księga Mądrości, Syracha, Barucha 1 Lamentacje. Jeśli natomiast chodzi o kanon Nowego Testamentu to w niczym prawie nie odbiega od kanonu trydenckiego, pomijając wątpliwości, które sam autor poematu traktuje drugorzednie. Sygnalizuje on bowiem pewne rozbieżności co do ilości listów katolickich, a takze co do kanonicznośc1 Apokalipsy św. Jana. Na zakończenie tego dość obszernego wprowadzenia mypada jeszcze dodać, że sam adresat poematu, Seleukos, jest postacia bliżej nieznana 1 trudną do zidentyfikowania. Sądzić raczej mozna, ze jego osoba posłuzyła tylko Amfilochiuszowi za pretekst dla poetyckiego wykładu swego programu chrześcijańskiego wychowania.

Właściwe, określone tematem, pole niniejszego opracowanta będzie obejmowało niejako dwie czésici. W pierwszej z nich zostanz przedstawione te dziedziny kultury helleńskiej, które nie zostały zaakceptowane przez program wychowania chrześcijańskiego. Druga cz̧̧ść natomiast będzie miała na celu uwypuklenie tych wartości hellenizmu, które zostały nplecione w treśc1 wychowawcze chrześciJaństwa.

Wŕ́ród negatywnych zjawisk kultury grecko-rzymskiej na plan pierwszy wysuma Amfilochiusz błędy 1 pułapki kryjące się turze pogańskiej. Aby wprowadzić w powyzsze zagadnienie, należy zwrócić uwage na lakt, że w IV 1 V wieku, mimo 1ż cesarstwo przyjęło formalnie religię chrześcijańska, nie było jeszcze szkół chrześcijańskich o profilu ogólnym, lecz nauka polegała nadal na czytaniu 1 komentowaniu klasycznych poetów, historyków 1 retorów helleńskich 29 . Kościół więc nteustannie przypominał, ze klasyczna 11teratura niesie zoba liczne niebezpieczeństwa, gdyz opiera sie na mitologil pogańskiej i jest tym samym niemoralna, niemniej jednak nie występowano wprost przeciw systemowi szkolnictwa, który Ja propagował ${ }^{30}$. Podobnie przestrzegał biskup Ikonium, aby z roz-

29. J. Szymusiak, Kościóz starożtny wobec innych religi1, AK 61 /1969/ t. 73, 238.

30 P. Filipek - A. Młotek, Postawa chrześcijan IV I V w. wobec kultury antyczneJ, RTK 29/1982/ z. 3, 11 . 
wagą przystępować do lektury pism pogańskich ${ }^{31}$, a jako przykład roztropności podawaz pszczołę ${ }^{32}$. W dalszej części swego wywodu Amfilochiusz uczula szczególnie na mity o bóstwach ${ }^{33}$ rozwijając tu niejako myśl św. Pawła /1 Tm 1, 4; 4, 7/. Autor "Jambów" podkreśla jednak, że nie nalezy odrzucać tego, co w opowiadaniach o bóstwach jest pożyteczne, a mianowicie elegancji słowa ${ }^{34}$. Wiaze się to z szerszym zagadnieniem formalnej zalezności pisarzy chrześcijańskich, 1 to zarówno greckich, Jak 1 lacińskich, od swoich poprzedników, 1 "z tego punktu widzenia piśmiennictwo chrześcijańskie jest tylko jednym dzlałem literatury schyłkowego okresu starożytnośc1, ale za to najświetniejszym" ${ }^{35}$. Wreszcie na zakończenie swego wykładu o literaturze helleńskiej autor, parafrazujac ewangelistów Mt 7, 16; Lk 6, 44/, formułuje bardzo zwięzłą, a przy tym niezwykle obrazowa maksymę: "Unikaj cierni /.../ zrywaj rózę"36. Kolejnym obszarem kultury helleńskiej, uwazanym przez chrześcijaństwo za zgubny z moralnego punktu widzenia, były obyczaje pogańskie. Sówiąc o nich Amfilochiusz posługuje się wypowiedzia św. Pawła Apostoła, ktory stwierdza, ze obcowanie ze złymi niszczy to, co szlachetne $/ 1$ Kor $15,33 /^{37}$. Autor "Jambów" przestrzega przed towarzystîem złych ludzi, których porównuje do zwierząt zarazonych świerzbem ${ }^{38}$. Pragna oni sprowadzić młodych ludzi na droge lajdactwa 39 aby przez to zaszkodzić Kościołowi Jako wspólnocie ${ }^{40}$. Uridacznia sie tu niezwykle ważny dla ówczesnego chrześcijaństwa problem stosunku do pogańskiej obyczajowości. Autorzy tego okresu dostrzegaja myraźnie jej destrukcyjny wpływ na zycie chrześcijan, a w szczególności na młode, nie uformowane jeszcze osobowośc1. Proponowano tu wiele rozwiqzań. Jednł z najbardziej radykalnych przedstawił apologeta II w. Tacjan Syryjczyk w dziele pt. "Jlowa przeciw Grekom", w którym

31 Jamby w. 39.

32 Tamze, w. 41-44.

33 Tamże, w. 53-56.

34 Tamze, w. 52-60.

35 M. Simon, Cywilizacja wczesnego chrześc1jaństwa, tłum. B. Bąkowska, Warszawe $1979,326$.

36 Jamby, w. 61.

37 Tamze, w. 76.

38 Tamze, w. 67-69.

39 Tamże,, 73 .

40 Tamze, w. 74 . 
odrzucal zdecydowanie wszystko co greckie jako oczywiste zło ${ }^{41}$. Równiez prawodawstwo w stosunku do pogan stawało się coraz surowsze. W 341 r. wydano rozporządzente zakazujace składania ofiar, a helleński retor Libanios wprost oskarżył cesarza Konstancjusza /337-361/ o burzente świątyń 1 zakaz sprawowania kultu ${ }^{42}$. Ten kierunek działań uległ chwilowemu załamaniu za rządów Juliana Apostaty /361-363/, który uważał, ze chrześcijanie, porzucając dziedzictwo kultury klasycznej, odrzucili zarazem nleocentone wręcz wartośc1 w celu prowadzenia zycia nacechowanego poświęcentem, zaparciem się siebie 1 umartwientami clała; wybrali zatem, jego zdaniem,ideał barbarzyriskiej 1 niewolniczej mentalności, która symbolizował kult "krwawiącego 1 konającego Boga"43. Jednakże już po jego śmierci cesarz Gracjan /375-383/ i Teodozjusz /375-395/przedsięwzięli liczne radykalne środki przeciw religil 1 obyczajowości pogańskiej. Całe antypogańskie prawodawstwo uwieńczył w listopadzie $392 \mathrm{r}$. edykt wydany wonstantynopolu, na mocy którego zabroniono wszystkim, bez względu na pozycje społeczną, czcić bałwanów, składać w ofierze choćby tylko napój lub kadzidło, a tym bardziej zwlerząt, oddawać czci bóstrom opłekuńczym domu, a także uprawiać haruspicja ${ }^{44}$. Ten krótki ekskurs dotyczący ustawodawstiva antypogańskiego, choć pozornie nieco odbiega od zasadniczego wątku rozważań, wydaje sie być niezwykle pomocny, gdyż ukazuje szersze tło rozpatrywanych tu zagadnień szczegółowych.

Wśród niebezpieczeństw, Jakie niesie z sobą kultura helleńska dla chrześcijańskiego wychowania młodzieży, najwięcej miejsca poświęca Amfilochiusz widowiskom pogańskim, wóród których wymienia widowiska teatralne, walki gladiatorów 1 polowania na dzikie zmierzęta urządzane w cyrku oraz wyścigi rydwanów na hipodromie ${ }^{45}$. Nazywa je "marnościa zycia", a ze wgględu na zawarte w nich niebezpleczeństwo porównuje je z hydraz ${ }^{46}$. Na plerwszym miejscu wśród

41 Oratio adversus Graecos, PG 6, 801-888, M. Michalsk1, Antologia literatury patrystycznej, $I$, hiarszawa 1975, 109-116.

42 M. Simon, dz. cyt., 231.

43 Ch. N. Cochrane, Chrześcijaństwo 1 kultura antyczna,tłum. G. Pianko, Warszawa 1960, 265.

44 M. Simon, dz. cyt., 267.

45 Jamby, $w$. 78-79.

46 Tamze, พ. 80. 
tego rodzaju pułapek wychowawczych stawia widowiska teatralne, z których wymienia mim 1 pantomimę. 0 aktorach mimicznych wyraża sie niezwykie dosadnie, twierdząc, ze szybciej obcięli sobie brzytwami wstyd niz zarost 47 . W jego oczach sa to ludzie wyzuci z wszelkiego poczucia przyzwoitości, a przeciwnie, bezwstydność poczytuja sobie za przejaw kunsztu ${ }^{48}$. Należy podkreślić, ze w tym okresie niebezpleczeństwo to było nader aktualne. W czasach cesarstwa bowiem, jak twierdzi L. Winniczuk ${ }^{49}$, mim zajłłł czołowe miejsce wśród widowisk, dystansując nawet poważną twórczość dramatyczną. Tekst nie odgrywa wim znacznej roli, aktorzy mieli dużą swobodę $w$ jego uzupełnianiu, w przedstawianiu, w aktualizacji, a nawet w improwizacji. Przedstawiano w nim przewaznie przygody miłosne, konflikty z życia codziennego, intrygi, a także zdrady małzeńskie. Idąc dalej za mywodem L. Winniczuk ${ }^{50}$, należy w aspekcie niniejszego tematu dodać, ze mimy atakowały także chrześcijanstro. W tym świetle jeszcze bardziej zrozumiała staje się nieprzejednana postawa Amfilochiusza.

Biskup Ikonium dostrzega jednak $i$ nędzniejsze, jak to określa, od mimów plemię 51 , którym są hańbiący "godność płci męskiej"52. Chodziło mu tu zapewne o aktorów grających role kobiece, zwłaszcza w pantomimie. Te widowiska,przewaźnie o treści mitologicznej, kończyły się niekiedy nawet rzeczywistá śmiercia aktorów, którymi często bywali skazańcy ${ }^{53}$. Aktorów pantomimy piętnuje Amfilochiusz jako zniewieściałych samców ${ }^{54}$. Nie sa to dla niego "ani męzczýnín, ani kobiety"55, gdyż "tym pierwszyn/.../ już nie są, drugim zaś, jeszcze sie nie stalin56. Zauważa przy tym szerszy kontekst tego rodzaju przedstawień, w których widzi "pułapkę rozwiazłości" 1 "sak

47 Tamze, w. 86 .

48 Tamże, w. 89.

49 L. Winniczuk, Ludzie, zwyczaje 1 obyczaje starożytnej Grecji 1 Rzymu, Warszawa 1983, 640 .

50 Tamże, 641.

51 Jamby, T. 90.

52 Tamż, w. 91.

53 R. Gostkowski, Wychowanie Pizyczne w starozytnośc1, Kraków 1928, 45.

54 Jamby, พ. 93.

55 Tamze, พ. 94.

56 Tamze, w. 95. 
poządliwych uczuć"57. Z mimem 1 pantomima łący Amfilochiusz "zaraze nieprzystojnych pieśni"58. Dla niego tego rodzaju muzyka jest czynnikiem "zniewieścienia siły duszy" ${ }^{59}$ boleje szczerze nad tymi, którzy w swej głupocie wyznaczaja nawet nagrody za tego rodzaju popisy 60 . Autor "Jambów" w końcowym eragmencie ustępu dotyczącego widowisk teatralnych, widząc powszechność rozpusty 1 wszelkiej zadzy ${ }^{61}$, apeluje w obrazowej metaforze do młodzież, by nie kalała tymi widowiskami swych zrenic, zachowując je niejako w dziew1 ctwie ${ }^{62}$.

Ten dramatyczny apel nie zamyka jednak kwestil zwizzzanych z niebezpleczeństwem widowisk pogańskich, lecz stanowi tylko podsumowanie plerwszego, rzecz można, etapu. W drugim bowiem etapie Amfilochiusz omawia walki gladiatorów z dzikimi zwierzętami. Warto tu przypomnieć, ze gladiatorami byli w pierwszym rzędzie ludzie zmuszeni siła do występowania na arenie, rekrutujący się z jeńców, przestępców, a w okresie prześladowań takze 1 chrześcijan ${ }^{63}$. Ich malki ze zwierzętami organizowano poczynając od roku 186 prz. Chr., najpierw w cyrku, a potem na arenach amfiteatrów, dokąd sprowadzano ogromne llości dzikich zwierzat nawet z najdalszych prowincji, głónie zaś z Afryki ${ }^{64}$. Te krwawe igrzyska odbywające sie w duźch miastach raz lub dwa razy w roku trwały przez kilka, a czasem nanet kilkanaście dni ${ }^{65}$. Gladiatorzy 1 ich nauczyciele, a takze ludzie organizujacy igrzyska od poczatku nie byl1 dopuszczani przez Kościóz do sakramentu chrztu. Ale nawet ogłoszenie chrześcijaństwa religia panujaca nie połozyło od razu kresu tego rodzaju imprezom ${ }^{66}$.

$\begin{array}{ll}57 & \text { Jamby, w. } 98-99 . \\ 58 & \text { Tamze, w. 100. } \\ 59 & \text { Tamż, w. 101. } \\ 60 & \text { Tamze, w. 104. } \\ 61 & \text { Tamż, w. 106-107. } \\ 62 & \text { Tamze, w. 111-113. }\end{array}$

63 M. Grant, Gladiatorzy, tłum. T. Rybowsk1, Wrocław 1979, 27 ; por. S. Longosz, Damnati ad bestias, TST $7 / 1979 / 82-103$.

64 R. Gostkowski, dz. cyt., 43.

65 R. Gostkowski, Sport w starożytnośc1, Warszawa 1959, 168.

66 M. Grant, dz. cyt., 88 . 
W tym kontekście zrozumiała staje się gwałtowność, z jaką przeciw nim cych w tych widowiskach, obzartuchami, dla których zołąuek jest bogiem $^{67}$ przedstawiajac przy tym obraz człowieka rzadzonego przez swóf własny żołądek ${ }^{68}$. Nawiazuje ponadto świadomle do określeń św. Pawła /lzz 16, 18; Flp 3, 19/, który analogicznymi sformułowaniami piętnuje niegodne zycie niektórych chrześcijan. Czy jednak m odniesientu do gladiatorów zostały one użyte pełni słusznie, pomoze zapewne rozstrzygnźć M. Grant, mówiąc o przygotowaniach do 1grzysk: "Posępny /.../ ceremoniał zaczynał się już w wigilię rozpoczęcla widowisk. Organizator lgrzysk urządzał wtedy wystawny bankiet dla zawodników mających nazajutrz wystąpić na arenie. /.../. Publiczność była dopuszczana do udziału wczcie, aby mogła na własne oczy zobaczyć, ze niczego tam zawodnikom nie skąpiono. /.../. Spośród biesiadników jedni, otępieni lub zrezygnowani, zdawali sie na bieg wypadków 1 zarłocznie się objadal1./.../. Zawodnicy greccy /.../ w czasie takich bankietów zegnali się z przyjaciółmi, gdy natomiast Trakowie 1 Celtowie mieli skłonność do objadania się"69. Być może, ze Amfilochiusz nie znał dokładnie tego ceremoniału, lub, co jest o wiele bardziej prawdopodobne, posłuzył sie takimi obrazami,aby wzczególny sposób obrzydzić ten typ ludzi, a co za tym Idzie 1 te formę widowisk. W dalszej części swego poematu przechodz1 on do charakterystyki widzów, obserwujących takie spektakle ${ }^{70}$, określając ich mianem "ludz1 okrutnych"71 i żądnych krwi ${ }^{72}$, których dzika ządza upodabnia do zwierząt ${ }^{73}$. Wiedział, ze miliony obywateli hołdowały tego rodzaju rozrywkom 1 zaniechanie $1 \mathrm{ch}$ mogło spowodoพać navet bunty 1 zamieszki ${ }^{74}$. Nie wstrzymuje się jednak od krytycznego ukazania walczacych na arenie gladiatorów, którzy staraja się uniknąć zagłady75, lecz zwykle zostaja dopadnięct przez przeciw-

67 Jamby, w. 115.

68 Tamze, $\pi .116-122$.

69 N. Grant, dz. cyt., 51.

70 Jamby, w. 123-136.

71 Tamze, w. 123.

72 Tamże, w. 131.

73 Tamze, w. 135-136.

74 M. Grant, dz. eyt., 81.

75 Jamby,, 124. 
ników 1 ponosza straszliwa śmierć:

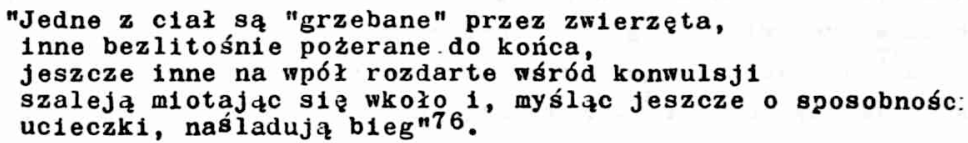

Nie mzrusza to jednak zupełnie widzów, którzy "raduja się $/ \ldots /$, patrząc na to, nad czym nalezałoby płakać"77. Rómniez sam Amfilochiusz niezbyt boleje nad ich losem, gdyz w gladiatorach widzi ludzi, którzy samych siebie sprzedali na śmieré:

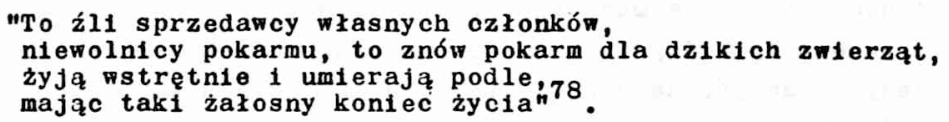

Jest to chyba najbardziej wstrząsający, a zarazem działający na wyobraźnię eragment poematu, whórym autor stara się bez reszty obnazyć ohydę 1 okrucieństwo tego rodzaju widowisk, oraz wywołać w świadomośc1 wychowankówilch nauczycieli niezatarty obraz bezmyśInego okrucieńs twa ${ }^{79}$.

Wreszc1e jako ostatni rodzaj widowisk wymienta Amfilochiusz wyścigi rydwanów na hipodromie, dodając, że wielu uwaźa je za bardziej przyzwoite od dwóch poprzednich ${ }^{80}$. Sam jednak jest odmiennego zdania, twierdząc, ze jest to "zaraza miast 1 choroba dusz" 81 , których skutki przedstawia następująco:

$\begin{array}{ll}76 & \text { Tamze, w. 141-145. } \\ 77 & \text { Tamze, w. 132. } \\ 78 & \text { Tamze, w. } 137-140 .\end{array}$

79 Wysiłk1 Kościoła zmierzającego do połozenia kresu tego rodzaju widowiskom, zostały uwieńczone sukcesem dopiero wiele lat po śmierci Amfilochiusza. Pojedynki gladiatorów zakończyły sie wprawdzie definitywnie w latach 439-440, ale walki z dz1kimi zwierzetani na arenie przetrwały az do roku 681. Por. M. Grant, dz.cyt., 89 .

80 Jamby, . 150-151.

81 Tamze,, 152. 


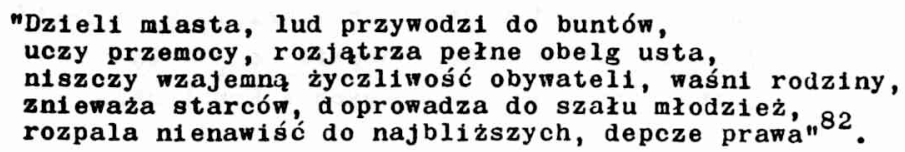

Mozna by dziś powledzieć, ze Amfilochiusz uwzględniał w swym programie wychowawczym nie tylko formowanie indywidualnego charakteru wychowanka, lecz także starał się go uwrażliwić na społeczny wymiar 1 znaczenie zdrowej postawy moralnej, posługujac sie w tym celu niejako "negatywem". Zręcznie wplata wę część poematu równiez wzmiankę o innym, równie szkodliwym zjawisku, a mianowicie - gusłach 1 czarach. Guślarze majaz przy pomocy demonicznych zaklę́ sprawić, aby rydwan przeciwnika uległ wypadkow1, a sam rywal doznaz obrażeń lub nawet poniósł śmierć ${ }^{83}$. Takie postęporvanie może przynieść radość tylko zastępowi demonów ${ }^{84}$, gdyż prowadzi do zguby dusz 1 walk1 ciał ${ }^{85}$. Moźe ono także doprowadzić, wskutek czynionych w czasie zawodów zakładów, do wielkich szkód majątkowych ${ }^{86}$. Tę część poematu kończy Amfilochiusz wizją buntu obywateli 1 jego stłumienia przez władcę. We wzburzonym mieście, jak pisze, zostaje wprowadzone prawo miecza ${ }^{87}$, rządzi w nim "ogień 1 żelazo"88, a efektem tego jest rzé́ i zbrodnia ${ }^{89}$. Jak wielki zaś zasięg oddziaływania miały w1dowiska hipiczne, niech świadczy lakt zupełnego ignorowania ustawy Konstantyna Wielkiego z $325 \mathrm{r}$., ograniczajacej te widowiska 90 . Równiez późniejsze analogiczne ustawy wielokrotnie nowelizowano. Za Teodozjusza, na przykład, nie wolno było w niedzielę urządzać przedstawień teatralnych, wyścigów konnych, ani innych rozrywek, chyba, 1 tu znów dowód na powszechność tych widowisk, że odbywały się one dla uświetnienia urodzin cesarza lub jakiejś rocznicy ${ }^{91}$.

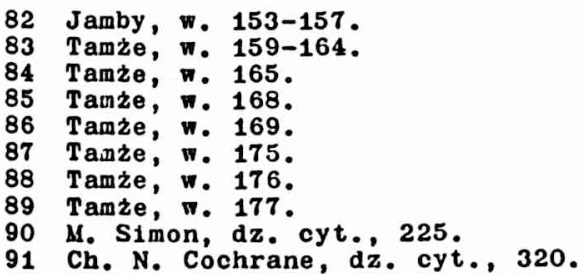


Nawet cesarze zatem nie byli w stanie radykalnie wykorzenić tego zwyczaju, który wonsekwencji doprowadził do powstania zwalczających się wajemnie Prakcji 1stniejazcych wonstantynopolu do IX w1 eku 92 .

Trzeba tu podkreślić, ze tę część poematu, która dotyczy dziedzin kultury helleńskiej nieakceptowanych w chrześc1jańskim programie wychowawczym, Amfilochiusz potraktował niezwykle powaznie, wrecz drobiazgowo. Starał sie oddziałać na czytelnika przede wszystkim poprzez akazanie okrucieństwa 1 społecznej szkodliwości danych zjawisk, pobudzać wyobraźnię 1 skłaniać do repleksj1. Wskazywał nie tylko na ogólne, szkodliwe w procesie wychowawczym zjawiska, lecz starał się na lch tle przedstawíc poszczególne, zakorzenione wówczas $w$ społeczeństwie wady. Przestrzega zatem, aby "nigdy nie popadać w pychą"93, gdyz jest to niewatpliwie najgorsza z wad, która odrzuca prawo moralne, jak 1 kazdą Inną zaleźność, aby wasną wole postawié nad wszelkim Innym autorytetem. Staje się przez to źródłem buntu ${ }^{94}$, bezbożności ${ }^{95}$, obelżywośc1 ${ }^{96}$, nienawisc1 $^{97}$, a ta z kolei rodzi okrucieństwo ${ }^{9}$, które juz nie liczy 81 e $z$ zadnym prawem 99 . Autor poematu wskazuje takze na takie wady jak poządíośćc ${ }^{100}$, bezwstyd ${ }^{101}$, zajdactwo ${ }^{102}$, czy wreszcie rozpuste $e^{103}$ 1 rozwiazłoścíc. Prócz tych piętnuje jeszcze kłótliwośc ${ }^{105}$, Jej przeciwieństwo-przymilnośc106, jak równiez marnotrawstwo 107. Wszystkie te wady nazywa "sidłami światan'108 i doczesna marnościa ${ }^{109}$.

92 R. Gostkowski, Wychowanie Pizyczne w starożytności, dz. cyt., 41.

93 Jamby, พ. 217. Por. พ. 234, 248.

94 Tamze, 1 . 153.

94 Tamie, N. 207.

96 Tamze, w. 154.

97 Tamze, w. 157.

98 Tamze, w. 123.

99 Tamże, w. 157.

100 Tamze, w. 98.

101 Tamze, ต. 83.

102 Tamze, พ. 73.

103 Tamze, w. 106.

104 Tamze, w. 81.

105 Tamze, N. 79, 167.

106 Tamż, w. 16.

107 Tamze, พ. 121.

108 Tamze, w. 320.

109 Tamze, w. 321. 
Zaden prawdziwy chrześcijanin nie może ich zaakceptorać, ale mu81 się na nie uodpornić. czym wielce miało pomóc wychowanie w duchu chrzé́c1jarisk1m.

Amfilochiusz Jednak nie tylko krytykował kulturę helleńska, ale odnosił sie takze z szacunkiem do wielu wartośc1 wypracowanych przez hellenizm, co starał sie takie przekazad w swym programle wychowawczym. Zalecał więc lekturę poetów 1 historyków, kunszt retorów, jak 1 rozwazania ellozofów110. Równoczé́nie jednak zachęcał do stakej czujności 1 rozrózniania między formą a treścia. Jeśliby bowiem natrafiono na treści niemoralne, dotyczace najczę́ciej mitycznych bóstw, nalezy je bezwzględnie odrzucić, przyjmujac jednakze szate słowną, która, jak to określa, ma w sobie wiele wdzięku ${ }^{111}$. Akcentował szczególnie naukę retoryki ${ }^{112}$, która ma być narzędziem do swobodnego wypowiadania 1 głoszenia prawdziwych wartości, zawartych głórnie w Piśmie św. ${ }^{113}$ To ostatnie jest,jego zdaniem, wyrazem mądrości Ducha Sw., która pochodzi od Boga ${ }^{114}$. Madrośc1 tej winno służyć całe wychowanie 1 wykształcenie "na dole"115, 1 to nie wóród próżnej pychy, lecz nw skromnoso1 116. Amfilochiusz nakazuje przekuó cała pozytywną część mądrośc1 helleńskiej na narzędzie $\mid$ słuzbie mądrośc1 Bożej, postulując, aby "mądrość ziemska była niewolnica mądrości Boga"117. W tym kontekście warto przypomnies, ze Kościóz nigdy nie potępiaz samych studiów świeckich 1 dopuszczał do nich młodzież, mimo ze ksztazc1ła sie ona u nauczycieli pogańskich ${ }^{118}$. Ostrzegał jednak, jak to równiez czyni Biskup Ikonium, ze literatura klasyczna karmi sie

110 Jamby,, . 35-38.

111 Tamze, $w_{0}$ 57-60.

112 Tamze, $⿴$. 241-242.

113 Tamze, w. 243-244.

114 Tamze, w. 245-246.

115 Tamie, w. 247.

116 Tamze, ต. 248-249.

117 Tamze, w. 250.

118 M. Simon, dz. cyt., 310. 
mitologia pogańską, przez co staje się niemoralna, niemniej jednak tolerował Ją Jako podstawe wszelkiego wychowania intelektualnego ${ }^{119}$. Kó́cióz zreszta, o czym nie należy zapominać, sam wiele zawdzięcza dorobkowi antyku. K. Hajewski ujął tę spuśc1znę w trzech zasadniczych punktach: zmysł wielkości przyjęty ze Wschodu, poczucie prawdy 1 piezkna zapożyczone od Greków oraz poczucie ladu 1 sprawiedl1woścl odziedziczone niejako w spadku po Hzymie ${ }^{120}$. Zaznacza on równiez, ze sama terminologla kościelna przyjęła niejedno z symbolicznego słownictwa poezj1 klasycznej, jak: uroczyste egzorcyzmy, święcenie wody, białe tuniki, świece, wreszcie procesje na wzór panatenajski ${ }^{121}$. Warto tu tez przypomnieć, ze chrześcijanie długo nie posiadali wasnych szkót na poziomie podstawowym $i$ średnim, a pojawiajace się od II w. wyzsze szkoły teologiczne nie przyjęły sie 1 z reguły działały krótico ${ }^{122}$. Z tego to również wynikała koniecznóś niemal całkowitego oparcia się na szkolnictwie helleńskim. Dominowała zaś nim retoryka, która nie tylko mdrażała do bległośc1 w mówioniu, lecz nadarała ogólna formacje intelektualna swym młodym adeptom ${ }^{123}$. Zrozumiałe zatem staje się znaczenie, jakie jej nadaje autor poematu. Wóród dyscyplin godnych poznania mymienia on także historie 1 fllozofię. W okresie sporów doktrynalnych, szczególnie trynitarnysh,historię interpretowano przewaznie wategoriach woll Boga. Taka interpretacja zostaka naszkicowana Juz w "De incarnatione" św. Atanazego, a pełny swój wyraz znalazła w "De civitate Dei" śn. Augustyna ${ }^{124}$. Jeśli chodzi o filozofie, to Sokrates, Platon 1 Arystoteles uchodzili w omawianym okresie za czołowych myślicieli czasów przechrześcijańskich ${ }^{125}$. Chrześcijaństwo dostrzegło wnet w Sokratesie tego, który pierwszy

119 M. Simon, dz. cyt., 311.

120 K. Majewski, Chrystianizm wobec starozytności, "Prąd" 22 $/ 1935 /$ t. 29,180 .

121 Tamze, 183.

122 H. J. Marrou, dz. cyt., 450.

123 S. Skimina, Istota 1 rola retoryki w starożytności, "Mfeander" $2 / 1947 /, 211$.

124 Ch. N. Cochrane, dz. cyt., 445.

125 J. Wabner, Nauki klasyczne w świetle chrześcijaństwa, Warszawa 1917,25 . 
uznał duszę za źródło najwyzszych ludzkich wartośc1, co z kole1 nadało zyciu nowy sens 1 wymiar, a zarazem skierowało myśl filozofiozna ku sprawom wewnętrznym, gdyz odtąd cnoty 1 szczęścia nalezało szukać w sercu człowieka126. Również "Państwo" Platona dotyczyło duszy ludzkiej, a tzw. organiczna koncepcja państwa miała na celu jedynie "powiększone odbicie" ludzkiej duszy wraz z jej wewnętrzna strukturą ${ }^{127}$.

Powyzsza charakterystyka pozwala, jak sle wydaje, lepiej rozumieć zalecenia Amfilochiusza jako twórcy programu wychowawczego. Cechuje go szerokie spojrzenie na cały ówczesny dorapek kulturowy, którego horyzonty stara się przekazać zarówno młodym, jak równiez 1ch nychowawcom. Należy takze podkreślić, iz program wychowawczy b1skupa Ikonium by realiach. Czytelników swego poematu odsyłał do konkretnej sprawdzalnef rzeczywistości. Końcowe wiersze "Jambów do Seleukosa", mówiące o szczęściu wiecznym ${ }^{128}$, wskazuja równocześnte na cel wychowania chrześcijańsiciego, którym jest wychowante do świętości. W ujęc1u tym widać zasadnicze róznice światopoglądowe między hellenizmem a chrześc1jaństwem. Starożtność pogańska nie operowała w zasadzie pojęciem zbawienia a śmierć była końcem wszystkiego. Grecy 1 Rzymianie zatem, nie widzac konkretnego teleologicznego sensu istnienia, zmuszeni byli szukać jego namiastk1, która upatrymali w sławie unieśmiertelniającej imię bohatera w pamięci potomnych. Stąd to ideałem wychowania u starożytnych było wychowanie ku sławie. Chrześcijaństwo natomiast ukazało cel ziemskiego zycia, którym jest zbawienie. Dla jego osi:łgnięcia przez możliwie największa liczbę ludzi, nalezało podjąć także odpowiednie kroki wychowawcze. System takiego oddziakywania, zapoczątkowany 1 niejako zaprogramowany przez Nowy Testament, by $z$ rozbudowywany 1 poszerzany w zalezności od warunków, w Jaikich przyszło działać poszczególnym Kościołom partykularnym. Program wychowania nakreślony przez Amfilochiusza z Ikonium jest tego klasycznym przykładem.

126 W.Jaeger, dz, cyt., t. 2, 94.

127 Tamże, 247.

128 Jamby, พ. 325-333. 


\section{LA CULTURE HELLENIQUE}

A LA LUMTERE DU PROGRAMATE D'EDUCATION D'AMPHILOQUE D'ICONIUM

$$
\text { Résumé/ }
$$

Dans son poème didactique intitulé "Janbi ad Seleucum" Amphiloque a présente d'une part les domaines de la culture gréco-romaine que le programme d'éducation chrétienne refuse avec fermeté. Ce sont des croyances et moeurs ainsi que des spectacles au sęng large du terme. D'autre part, Amphiloque a mis l'accent sur l'élément positif de l'acquis de la culture hellénique en le considérant comme une propédeutique de l'Ecriture Sainte. Car le but et. l'idéal de l'éducation chretienne constituent une éducation qui mène vers la sainteté, ce qui a trouvé son expression dans les derniers vers du poéme. 